\title{
Human Immunodeficiency Virus Positive
}

National Cancer Institute

\section{Source}

National Cancer Institute. Human Immunodeficiency Virus Positive. NCI Thesaurus. Code C15175.

A laboratory test result indicating the presence of the human immunodeficiency virus (HIV) in a sample. 